University of Nebraska - Lincoln

DigitalCommons@University of Nebraska - Lincoln

Agronomy \& Horticulture -- Faculty Publications

Agronomy and Horticulture Department

1995

\title{
Influences of Trees on Abundance of Natural Enemies of Insect Pests: A Review
}

\author{
Mary Ellen Dix \\ United States Department of Agriculture Forest Service \\ R. J. Johnson \\ University of Nebraska-Lincoln, ronj@clemson.edu \\ Mark O. Harrell \\ University of Nebraska-Lincoln, mharrell2@unl.edu \\ Ronald M. Case \\ University of Nebraska-Lincoln, rcase2@neb.rr.com \\ Robert J. Wright \\ University of Nebraska-Lincoln, rwright2@unl.edu
}

See next page for additional authors

Follow this and additional works at: https://digitalcommons.unl.edu/agronomyfacpub

Part of the Plant Sciences Commons

Dix, Mary Ellen; Johnson, R. J.; Harrell, Mark O.; Case, Ronald M.; Wright, Robert J.; Hodges, Laurie; Brandle, James R.; Schoeneberger, Michelle M.; Sunderman, N. J.; Fitzmaurice, R. L.; Young, Linda J.; and Hubbard, Kenneth G., "Influences of Trees on Abundance of Natural Enemies of Insect Pests: A Review" (1995). Agronomy \& Horticulture -- Faculty Publications. 412.

https://digitalcommons.unl.edu/agronomyfacpub/412

This Article is brought to you for free and open access by the Agronomy and Horticulture Department at DigitalCommons@University of Nebraska - Lincoln. It has been accepted for inclusion in Agronomy \& Horticulture -Faculty Publications by an authorized administrator of DigitalCommons@University of Nebraska - Lincoln. 


\section{Authors}

Mary Ellen Dix, R. J. Johnson, Mark O. Harrell, Ronald M. Case, Robert J. Wright, Laurie Hodges, James R. Brandle, Michelle M. Schoeneberger, N. J. Sunderman, R. L. Fitzmaurice, Linda J. Young, and Kenneth G. Hubbard 


\title{
Influences of trees on abundance of natural enemies of insect pests: a review*
}

\author{
M.E. DIX ${ }^{1}$, R.J. JOHNSON ${ }^{2}$, M.O. HARRELL ${ }^{2}$, R.M. CASE ${ }^{2}$, \\ R.J. WRIGHT ${ }^{3}$, L. HODGES ${ }^{4}$, J.R. BRANDLE ${ }^{2}$, M.M. SCHOENEBERGER', \\ N.J. SUNDERMAN ${ }^{2}$, R.L. FITZMAURICE ${ }^{2}$, L.J. YOUNG ${ }^{5}$, and \\ K. G. HUBBARD 6 \\ 'USDA Forest Service, Center for Semiarid Agroforestry, Lincoln, NE 28583-0822, USA; \\ ${ }^{2}$ Department of Forestry, Fisheries and Wildlife, University of Nebraska, Lincoln, NE 68583, \\ USA (UNL); ${ }^{3}$ Department of Entomology, South Central Research and Extension Center, Clay \\ Center, NE 68933, USA; ${ }^{4}$ Department of Horticulture, ${ }^{5}$ Department of Biometrics, ${ }^{6}$ Department \\ of Agricultural Meteorology, University of Nebraska, Lincoln, NE 68583, USA
}

Key words: arthropods, birds, predators, spiders, windbreaks

\begin{abstract}
In this article we review the use of natural enemies in crop pest management and describe research needed to better meet information needs for practical applications. Endemic natural enemies (predators and parasites) offer a potential but understudied approach to controlling insect pests in agricultural systems. With the current high interest in environmental stewardship, such an approach has special appeal as a method to reduce the need for pesticides while maintaining agricultural profitability. Habitat for sustaining populations of natural enemies occurs primarily at field edges where crops and edge vegetation meet. Conservation and enhancement of natural enemies might include manipulation of plant species and plant arrangement, particularly at these edges; and consideration of optimum field sizes, number of edges, and management practices in and near edges. Blending the benefits of agricultural and forestry (windbreak) systems is one promising approach to field edge management that has additional benefits of wind protection and conservation of desirable wildlife species.
\end{abstract}

\section{Introduction}

Agriculture must face the demands of competition in a global marketplace and increasing pressures for long-term environmental stewardship. In the past farmers have depended upon synthetic pesticides to control insect pests and produce more crops. This has created problems such as resistance to pesticides, unintentional pesticide damage to nontarget organisms, and contamination of the environment. New approaches are needed to attain long-term environmental stewardship objectives and efficient crop production. One approach is to blend the benefits of agricultural and forestry practices into

\footnotetext{
* Journal series 10549 of the Agriculture Research Division, University of Nebraska - Lincoln. This material was prepared with the support of USDA Agreement 91-COOP-1-6592 for the USDA/EPA Program, Agriculture in Concert with the Environment. Any opinions, findings, conclusions or recommendations expressed herein do not necessarily reflect the views of the US Department of Agriculture or the US Environmental Protection Agency.
} 
more sustainable land management systems. The conservation and enhancement of native or endemic natural enemies is one possible alternative. In this paper we review the use of endemic natural enemies to manipulate insect pests in agroforestry systems, discuss potential approaches, and identify research needs.

\section{Controlling pests with endemic natural enemies}

Endemic populations of natural enemies such as parasitic wasps (Hymenoptera), ants (Hymenoptera: Formicidae), ladybird beetles (Coleoptera: Coccinellidae), birds, rodents, and spiders (Araneae) have regulated the abundance of most damaging insects for millions of years. Natural enemies are probably most successful in stable forest ecosystems, where they keep populations of over $90 \%$ of arthropod herbivores below outbreak levels and eventually control most forest pests that do reach outbreak levels [Mason, 1987]. For example, bird communities and arthropod predators exert sufficient feeding pressure on low-density spruce budworm (Choristoneura fumiferana (Clem.)) populations to dampen the seriousness of infestations [Crawford and Jennings, 1989]. Spiders are important predators of the Douglas-fir tussock moth (Orgyia pseudotsugata (McDunnough)), western spruce budworm (Choristoneura occidentalis Freeman), and other defoliators [Mason, 1992]. Birds reduce populations of the larch sawfly (Pristiphora erichsonii [Buckner and Turnock, 1965], Douglas-fir tussock moth [Torgersen and Mason, 1987], and gypsy moth (Lymantria dispar (L.) [Whelan et al., 1989]. Although vertebrate and invertebrate natural enemies are unlikely to control widespread pest outbreaks quickly, they do have a role in preventing outbreaks through predation when pest numbers are low to moderate [Dahlste et al., 1977].

Areas of low diversity seem especially vulnerable to pest outbreaks. In the Knesha area of Bulgaria, an explosion of field rodent populations in recent years resulted in crop losses of up to $20-25 \%$ of the planted seed and emerging seedlings (H.D. Jose, University of Nebraska, Lincoln; W. Petersen, USDA Soil Conservation Service. Iowa City, Iowa; and N. Danielson, farmer, Rochert, Minnesota; unpub. report). Apparently, the underlying cause of the rodent outbreak was the nearly complete lack of natural habitat diversity and natural enemies resulting in an unstable system. Agricultural areas in northeastern Bulgaria, which had comprehensive windbreak plantings, had no such rodent problems.

In agricultural systems, endemic natural enemies are seldom used for long-term regulation of pest populations and reports in the literature are infrequent. Available information for vertebrate and invertebrate natural enemies is summarized below. 
Vertebrate natural enemies in agriculture

Zhang [1992] reviewed the role of birds in biological pest control in China and described several studies in which birds considerably reduced pest problems. Others in the United States have presented similar perspectives on the potential ecological value of birds in suppressing agricultural pest populations [Black et al., 1970; Getz and Brighty, 1986; Stewart, 1975]. Trnka et al. [1990] studied a windbreak-crop system in Moravia (Czechoslovakia), and argued that windbreaks enhance the diversity of vertebrate and invertebrate organisms and the self-regulating processes associated with system stability.

Johnson and Beck [1988], in a review of shelterbelt literature, reported that at least 108 species of birds and 28 species of mammals use shelterbelt habitats. In agricultural areas, 29 species of birds benefit substantially from shelterbelts, 37 moderately, and 42 very little or accidentally. At least 57 species of birds have been recorded using shelterbelts during the breeding season and, of these, 28 are known to nest in them. In Iowa and Illinois, woody edge habitat contained about seven times as many birds and twice as many breeding bird species (50 species) as herbaceous edge habitats [Best et al., 1990]. Cornfield perimeters $(<50 \mathrm{~m}$ from edge) had six to seven more bird species and five times as many individual birds than did field centers [Best et al., 1990]. Although species composition of birds in adjacent cornfields was influenced by type of edge (woody versus herbaceous), edge type did not significantly affect the overall numbers and species richness of birds in the cornfields.

Other research in the midwestern United States has shown the importance of grassed waterways [Bryan and Best, 1991], riparian areas [Stauffer and Best, 1980], and fencerows [Best, 1983; Shalaway, 1985], as edge habitats for birds in agricultural landscapes. Trnka et al. [1990] found 50 avian species in a windbreak-crop (barley, wheat, corn) system of which seven occurred exclusively in fields and 33 exclusively in windbreaks, leaving 10 species that used both habitat areas. There were 965 individuals representing 43 species recorded in the windbreaks, while only 414 individuals of 17 species were recorded in the fields. The observers found 10 small mammal species (207 individuals) in windbreaks and 5 species (66 individuals) in fields, but sampling techniques may have obscured the presence of others in the fields [Trnka et al., 1990].

Summers-Smith [1988] cited reports from Germany on the use of the Eurasian tree sparrow (Passer montanus) to control fruit tree pests and asparagus beetles (Crioceris aspergi (Linnaeus) (Coleoptera: Chrysomelidae)). Nest boxes were used to enhance Eurasian tree sparrow abundance. In a similar example, Summers-Smith [1988] reported that a Eurasian tree sparrow eradication program in China, described in detail by Suyin [1959], was followed by insect outbreaks and crop damage. Apparently the sparrow eradication campaign, intended to reduce grain losses, was based on oversimplification 
of a complex biological balance; the endemic tree sparrow has now returned to favor in China and is even encouraged [Summers-Smith, 1988].

\section{Invertebrates}

In Africa, abundance of Oecophylla longinoda (Hymenoptera: Formicidae), a predator of an hemipteran pest of cocoa and a coreid pest of coconuts, can be increased by interplanting cocoa with coconut palms and olive trees [Way, 1954]. In China, the intercropping of rice with cypress trees substantially increases spider abundance in rice fields and significantly decreases the abundance of the brown plant hopper, Nilaparvata lugens (Homoptera), a pest of rice [Shi and Gao, 1986]. In the United States, spiders play an important role in stabilizing populations of crop pests [Riechert and Lockley, 1984] and similarly may help to stabilize populations of tree pests.

No reports have been found comparing the numbers of species and individuals of arthropods in windbreaks and fields, but some information is available on migration patterns. In North Dakota, late instar larvae of the predaceous beetle Malachius ulkei Horn (Coleoptera: Malachiidae) migrate to Siberian elms (Ulmus pumila L.) in early spring and feed on spring cankerworm eggs (Paleacrita vernata Peck). About the time the cankerworm eggs hatch, M. ulkei disappear from the trees and presumably migrate back to the germinating crops to feed on small organisms and decaying plant matter. $M$. ulkei apparently search for food in the windbreaks when food is scarce in the surrounding crops [Dix, 1990]. It appears that spiders concentrate in field windbreaks in early spring before crops germinate and then disperse into the surrounding vegetation as the crops mature and feed on arthropods (M.E. Dix, personal observation). Further, the calmer air on the leeward side of windbreaks is well suited for bats, birds, and dragonflies to attack flying insects.

\section{Edges and natural enemy populations}

Farming, urban development, and other practices have destabilized most of the ecosystems that provided long-term habitat for natural enemies of insect pests. In the Great Plains of the United States, intensive farming systems have replaced much of the native grassland and associated fauna. In these humanmodified agricultural areas with extensive moncultures and few edges, windbreaks and similar woody habitat provide many benefits to agriculture including habitat for natural enemies. Benefits to natural enemies include protection from wind and adverse weather, escape or refuge cover, food and foraging sites, reproductive habitat, and travel corridors (Fig. 1). Benefits to agriculture include soil protection, moisture conservation and improved crop yields and profits [Brandle et al., 1988, 1992]. These woody edges contain tree, scrub, grass, and forb species that were originally found in the Great 


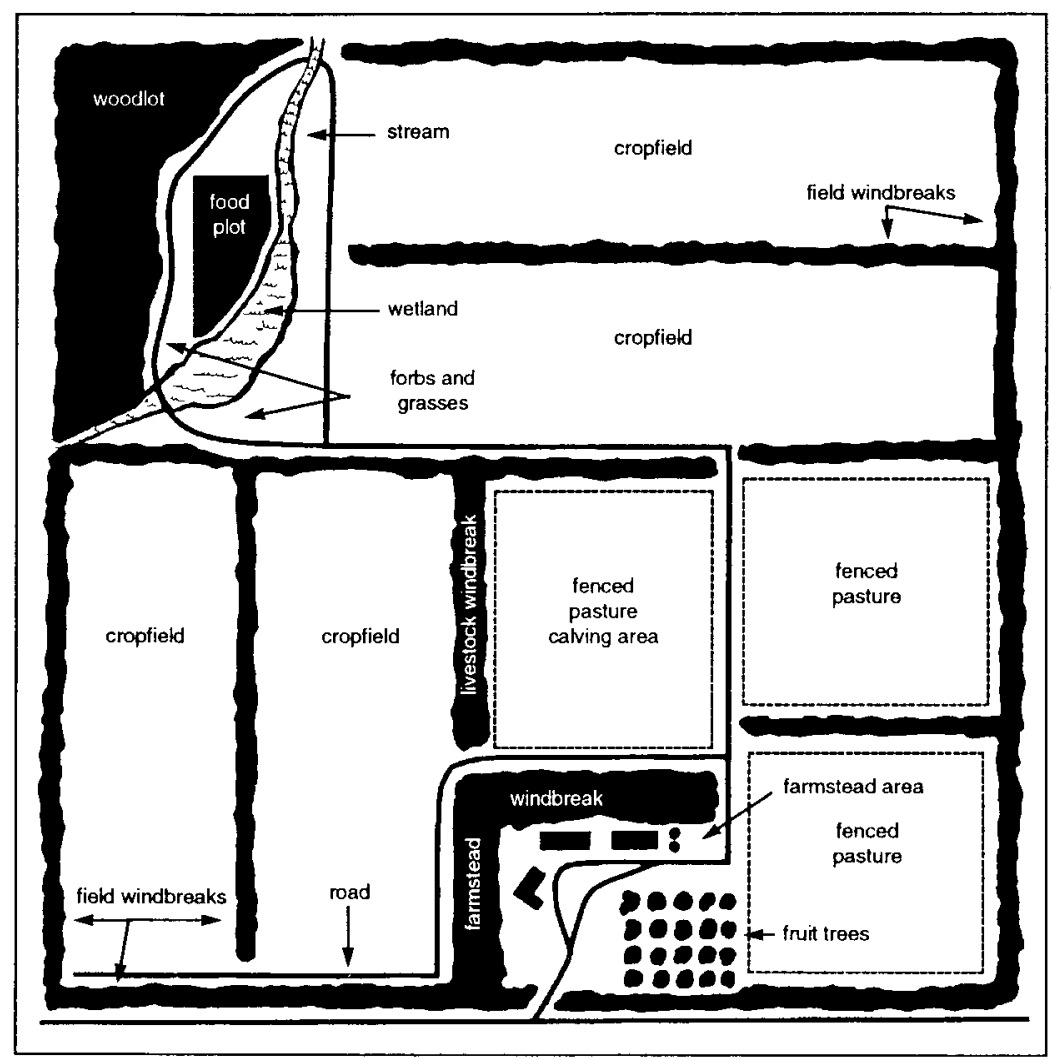

Fig. 1. An example of a 160-acre farm designed to take full advantage of multispecies windbreaks and other woody plantings to increase biodiversity, natural enemy abundance, and cconomic returns.

Plains. Proper management of these systems may increase long-term survival and sustainability of natural enemy populations, especially those common to both ecosystems [Dix, 1991, 1993; Dix and Donthiri, 1993; Johnson and Beck, 1988; Johnson et al., 1993; Trnka et al., 1990].

Predators associated with edges may affect crop pests in either the edge or the crop field. For example, predators living in a windbreak may forage in the crop field or, alternatively, may consume pest insects that are blown to the edge by strong winds or are attracted there for some life cycle need. In the Great Plains, windbreaks have not been designed to manipulate predator populations for crop pest control, however, predators have been observed feeding on insect pests and searching windbreaks for food (M.E. Dix, N.J. Sunderman, personal observations). 
308

\section{Structural and cultural diversity}

Trees and other tall vegetation can provide the vertical structure needed by spiders and birds. Flowering shrubs, herbs, and annual and perennial forbs can provide food for parasitic ichneumonids and syrphids that feed on flower nectar and pollen. The syrphids are predators of aphids [Leius, 1967] and are more abundant in areas of high floral diversity and abundance [Ruppert and Moltan, 1991]. Aphids that feed on goldenrod can be used as alternative prey for ladybird beetles (Coccinellidae) when populations of their primary prey are low [Altieri and Whitcomb, 1979]. In New Mexico, the predator Amara spp. (Coleoptera: Carabidae) is more abundant in juniper grasslands than in sagebrush, shrubland, or pine woodlands, due to the abundance of suitable small prey on the juniper (Juniperus spp.) [Steinberger et al., 1991].

\section{Overwintering sites}

Windbreaks can be used by arthropod predators as overwintering sites if appropriate vegetation is available. In South Carolina, certain species of coccinellids that feed on insect pests of field and orchard crops overwinter at field edges in herbaceous vegetation, grass, and tree litter [Roach and Thomas, 1991]. Woody field edges can provide habitat for birds or small mammals that feed on insect pests during the winter [Black et al., 1970; Johnson and Beck, 1988].

\section{Cultural practices}

Cultural practices such as plowing, cultivating and harvesting can radically alter the abundance of predators such as spiders, birds, and small mammals. Clean cultivation of a field or around trees may increase crop survival but also can decrease survival of birds, small mammals, spiders, or carabids that use the vegetation for shelter. For example, raking hackberry leaves from lawns removes parasites of the hackberry nipplegall maker (Pachypsylla celtidismamma (Fletcher) Homoptera: Psyllidae)), an insect that overwinters in the leaf galls. In rural areas, the leaves are not removed and the parasites control the psyllids (W. Cranshaw, Colorado State University, personal communications). Likewise, crop stubble left in fields might contain overwintering parasitic wasps or may provide cover for predators such as birds, overwintering spiders, or beetles.

\section{Pesticide use}

Although pesticides are the most frequently used method of controlling pests, most pesticides kill not only the target pest but many of its invertebrate natural enemies. They also may adversely affect vertebrate natural enemies and other nontarget organisms and, over time, most insect pests can develop resistance 
to a pesticide. Minimizing the use of pesticides, proper selection and application of pesticides when needed, and use of other integrated pest management techniques when possible are methods of reducing these adverse effects and conserving natural enemy abundance.

\section{Windbreak design}

Windbreak design is another method of manipulating natural enemy abundance, and diversity. In North Dakota, carabids and staphylinids (Coleoptera) that feed on crop pests were more abundant at the edge of multi-row windbreaks than in the interior of the windbreak [Katayama, 1980]. In single-row elm windbreaks, most of the windbreak is edge; thus, carabid and staphylinid abundance should be relatively constant across the windbreak [Frye et al., 1988]. Conversely, insectivorous birds establish large territories and prefer larger, wider windbreaks. Other species may benefit from curved or undulating windbreak designs that provide greater amounts of edge and less exposure when feeding in fields near the edge [PFRA, undated].

\section{Research needs}

Information is extremely limited on how crop and tree management practices affect the abundance of pests and their natural enemies in the Great Plains. To address this lack of basic information, the USDA Forest Service Center for Semiarid Agroforestry, the University of Nebraska, and the Nebraska Forest Service are conducting cooperative research to determine the impact of woody field edge vegetation on crop yields and on natural enemy and pest populations. A long-term goal of this research is to develop guidelines for managing agroforestry systems including techniques for enhancing beneficial endemic vertebrates and invertebrates as an alternative to the use of pesticides.

Biological control research within the Great Plains and elsewhere in North America is hampered by a number of factors. For example, accurate identification of arthropods and their natural enemies is essential since each species has different needs and behaviors. This process has been hindered by a shortage of arthropod taxonomists and appropriate reference collections. As a consequence there is a need to develop more accurate methods for identifying pests and to provide appropriate identification techniques for both entomologists and nonentomologists [Dix, 1993; Dix et al., 1993].

Information on biologies and long-term population trends is available for only a few pests and natural enemies. The impact of other components of the ecosystem and management practices on these pests and natural enemies is poorly understood. Most pest management practices are targeted toward controlling one specific pest and frequently have not been integrated into longterm systems management. Increased cooperation among disciplines and 
agencies with similar goals and strategies would help address these problems and enhance the development of biological control management techniques. Administrators need to encourage these multi-discipline and multi-agency projects and provide support for and recognition of all scientists involved in these cooperative efforts [Dix, 1993; Dix et al., 1993].

\section{References}

Altieri MA and Whitcomb WH (1979) The potential use of weeds in the manipulation of beneficial insects. Horticulture Science 14: 12-18

Best LB (1983) Bird use of fencerows: implications of contemporary fencerow management practices. Wildlife Society Bulletin 11: 333-347

Best LB, Whitmore RC and Booth GM (1990) Use of cornfields by birds during the breeding scason: the importance of edge habitat. American Midland Naturalist 123: 84-99

Black ER, Jr, Davis FM, Henderson CA and Douglas WA (1970) The role of birds in reducing overwintering populations of the southwestern corn borer, Diatraea grandiosella (Lepidoptera: Crambidae), in Mississippi. Annals of the Entomological Society of America 63: 701-706

Brandle JR, Hintz DL and Sturrock JW (1988) Windbreak Technology. Elsevier Science Publishers, $598 \mathrm{pp}$

Brandle JR, Johnson BB and Akeson T (1992) Field windbreaks: are they economical? Journal Production Agriculture 5: 392-398

Bryan GG and Best LB (1991) Bird abundance and species richness in grassed waterways in Iowa rowcrop fields. American Midland Naturalist 126: 90-102

Buckner CH and Turnock WJ (1965) Avian predation on the larch sawfly, Pristiphora erichsonii (Htg.) (Hymenoptera: T'enthredinidac). Ecology 46: 223-236

Crawford HS and Jennings DT (1989) Predation by birds on spruce budworm Choristoneura fumiferana: functional, numerical, and total responses. Ecology 70: 152-163

Dahlste DL, Luck RF, Schlinger EI, Wenx JM and Copper WA (1977) Parasitoids and predators of the Douglas-fir tussock moth, Orgyia Pseudotsugata (Lepidoptera: Lymantridae), in low to moderate populations in Central California. The Canadian Entomologist 109: 727-746

Dix ME (1990) Malachius ulkei Horn (Coleoptera: Malachiidae): an egg predator of Paleacrita vernata Peck (Lepidoptera: Geometridae). Journal of the Kansas Entomological Society 63(4): $648-652$

Dix ME (1991) Distribution of arthropod predators of insect pests in and near windbreaks. In: Proceedings of North American Symposium on Agroforestry [August 19-22, 1991 , Springfield, MOJ, pp 295-301. School of Natural Resources, Columbia, MO

Dix ME (1993) Conservation and enhancement of arthropod natural enemies of insect pests. Paper presented at the Symposium on Biological Control of Forest Pests in the Great Plains; Status and Needs, conducted by Great Plains Agricultural Council, Forestry Committee's Forest Biological Control Task Force [Bismarck, North Dakota, June 13-16, 1992], pp 72-76

Dix ME and Donthiri S (1993) Opportunities for biological control of insect pests in agroforestry systems. In: Proceedings 1992 Society American Foresters National Convention [Richmond, Virginia, October 25-28, 1992], pp 278-284

Dix ME, Walla J, Harrell M, Klopfenstein N and MacFall J (1993) Biological control of forest pests in the Great Plains: status, needs and issues. In: Proceedings of 44th Annual Meeting: Great Plains Agricultural Council Forestry Committee. Biological Control of Forest Pests in the Great Plains: Status and Needs [July 13-16, 1992, Bismarck, North Dakota] 45: 44-52

Frye RD, Dix ME and Carey DR (1988) Effects of two insecticides on abundance of insect families associated with Siberian elm windbreaks. Journal Kansas Entomological Society 61(3): $278-284$ 
Getz LL and Brighty E (1986) Potential effects of small mammals in high-intensity agricultural systems in east-central Illinois. USA Agriculture, Ecosystems and Environment 15: 39-50

Johnson RJ and Beck MM (1988) Influences of shelterbelts on wildlife management and biology. Agriculture, Ecosystems and Environment 22/23: 301--335

Johnson RJ, Brandle JR, Fitzmaurice RL and Poague KL (1993) Vertebrates for biological control of insects in agroforestry systems. Paper presented at the Symposium on Biological Control of Forest Pests in the Great Plains; Status and Needs, conducted by Great Plains Agricultural Council, Forestry Committee's Forest Biological Control Task Force [Bismarck, North Dakota, June 13-16, 1992], pp 77-84

Katayama RW (1980) Seasonal abundance of insects in shelterbelts. PhD thesis. Department of Entomology, North Dakota State University, Fargo, ND, $216 \mathrm{pp}$

Leius K (1967) Influence of wild flowers on parasitism of tent caterpillars and codling moth. Canadian Entomologist 99: 444-446

Mason RR (1987) Nonoutbreak species of forest Lepidoptera. In: Barbosa P and Schultz JC (eds) Insect Outbrcaks, pp 31-57. Academic Press, New York

Mason RR (1992) Populations of arboreal spiders (Araneac) on Douglas-firs and true firs in the interior Northwest. Environmental Entomology 21: 75-89

McEwen LC (1987) Function of insectivorous birds in a shortgrass IPM system. In: Capinera JL (ed) Integrated Pest Management on Rangeland, pp 324-333. Westview Press, Boulder

Nealis VG (1991) Natural enemies and forest pest management. The Forestry Chronicle 67: $500-505$

PFRA, Prairic Farm Rehabilitation Administration (undated) Planting trecs for wildlife. PFRA Shelterbelt Centre, Indian Head, Saskatchewan, Canada

Riechert SE and Lockley T (1984) Spiders as biological control agents. Annual Review Entomology 29: 299-320

Roach SH and Thomas WM (1991) Overwintering and spring emergence of three coccinellid species in the Coastal Plain of South Carolina. Environmental Entomology 20(2): 540-544

Ruppert $\mathrm{V}$ and Moltan J (1991) Augmentation of aphid antagonists by field margins rich in flowering plants. In: Polgar L, Chambers RJ, Dixon AFG and Hodek I (cds) Bchavior and Impact of Aphidophaga, pp 243-247. SPB Academic Pub bv, The Hague, The Netherlands

Shalaway SD (1985) Fencerow management for nesting birds in Michigan. Wildlife Society Bulletin 13: 302-306

Shi $Z$ and Gao Z (1986) On the ecological efficiency of shelterbelt network and its yield increasing effect in paddy fields. Journal of Ecology 5(2): 10-14

Stauffer DF and Best LB (1980) Habitat selection by birds of riparian communities: evaluating effects of habitat alterations. Journal of Wildlife Management 44: I-15

Steinberger Y, Aldon EF and Whitford WG (1991) Ground-dwelling arthropods of the Rio Puereo Watershed, New Mexico. Arid Soil Research and Rehabilitation 5: 147-153

Stewart PA (1975) Cases of birds reducing or eliminating infestations of tobacco insects. Wilson Bulletin 87: 107-109

Summers-Smith JD (1988) The Sparrows. T \& AD Poyser, Calton, UK, 342 pp

Suyin H (1959) The sparrow shall fall. New Yorker 35(34): 43-50)(10) Oet 1959)

Torgersen TR and Mason RR (1987) Predation on egg masses of the Douglas-fir tussock moth (Lepidoptera: Lymantriidae). Environmental Entomology 16:90-93

Trnka P, Rozkosny R, Gaisler J and Houskova L (1990) Importance of windbreaks for ecological diversity in agricultural landscape. Ekologia 9: 241-257

Way MJ (1954) Studies on the association of the ant Oecophylla longinoda (Formicidae) with the scale insect Saissetra zanzibarensis (Coccidac). Bulletin Entomology 5: 113-134

Whelan CJ, Holmes RT and Smith IIR (1989) Bird predation on gypsy moth (Lepidoptera: Lymantriidac) larvac: an aviary study. Environmental Entomology 18: 43-45

Zhang Z (1992) The use of beneficial birds for biological pest control in China. Biocontrol News and Information 13: 11 N-16N 